\title{
nature
}

\section{Hollow apologies should be avoided}

The head of the Max Planck Society is right to resist pressures to apologize for the actions of a previous generation. But acknowledgement and condemnation cannot come too soon.

C( is not within the moral authority of those who did not directly take part [in Nazi experiments on humans] to ask forgiveness for unforgivable crimes on behalf of others." Writing in the weekly newspaper Die Zeit, Hubert Markl, president of the Max Planck Society (MPS), puts his finger on a quandary that continues to deeply trouble many in the German scientific community: how should the postwar generation of scientists deal with the crimes committed in the name of medical research during the Third Reich?

Most scientists seem to agree that formal apologies to surviving victims of the experiments is in order, and long overdue. In the first decades after the war a conspiracy of silence reigned over the role of scientists supported by the Kaiser Wilhelm Society (KWS, the forerunner of the MPS) and the Deutsche Forschungsgemeinschaft (DFG) in such experiments. Silence was important to the scientists who moved into key positions in the postwar scientific community. It was broken in the 1980s when academics such as geneticist Benno Muller-Hill published evidence linking scientists who continued to head research institutes after the war to these crimes.

Pressure on the MPS and the DFG to apologize to the survivors of such experiments while they are still alive has increased, particularly since the 55th anniversary of the freeing from Auschwitz a few weeks ago. Many academics argue that Willy Brandt was prepared to kneel at the Warsaw ghetto 30 years ago and ask forgiveness for the crimes against Jews committed by Germans during the Third Reich (indeed, German president Johannes Rau only last week apologized in the Israeli parliament): surely representatives of research organizations should be prepared to do the same?

\section{Apology too easy}

However, what is generally accepted as appropriate action for Brandt, elected chancellor of a nation whose majority had lived through the war, appears not to be a simple matter to the war babies who now run German research organizations. Markl argues that apology is too easy and gives more to those who apologize - in particular an easing of conscience - than to those asked to accept the apology.

Markl's views have not brought him popularity in a society that struggles with the concept of collective guilt. But his reasons for holding back are based on a morality that has been well thought through, resists emotional pressure and detachedly considers the position of those who are not personally responsible and of those, still alive, who suffered.

The crimes committed are too great to allow forgiveness, he argues. Baby-boomers should not trivialize them by seeking forgiveness on behalf of others now dead, who, for all we know, might not even regret what they did. Apologies are not useful to the victims. More important is an explicit portrayal of what happened. At Markl's behest, the MPS recently launched a five-year research programme, run by science historians who are completely independent of the MPS, into the history of the KWS during the Third Reich. Markl, who says that this should have happened years ago, wants to wait for the results of the programme before deciding if an apology is due, or helpful.

Markl is alone among the heads of Germany's main research organizations in his stand against apology. His position angers some who see a moral duty to apologize, and bemuses others who know that it may be easy, and even self-serving, to apologize, but feel that it cannot be intrinsically wrong, and at least nothing would be lost. But his arguments are generally sound.

\section{Consult survivors}

Nevertheless, the scientific community's appropriate sensitivity to the crimes of its predecessors cannot appear to be ignored. That could lead to accusations that the MPS is in effect perpetuating a conspiracy that protected KWS scientists who continued their research careers with the MPS after the war - exactly what Markl wanted to avoid by making the research group independent, and well-resourced.

Moreover, Markl appears to confuse his own arguments by not separating the issue of apology from the work of this independent research group. There is already sufficient evidence for the shameful involvement of KWS scientists in Nazi experiments, and even 50 years of research will not provide a comprehensive and definitive picture of what happened.

Ernst-Ludwig Winnacker, president of the DFG, has suggested a different way around the conundrum. The DFG is continuing to investigate its own role in funding research that supported Nazi policies. Winnacker believes that there is already enough evidence to warrant an apology from the DFG before investigations are complete. But, like Markl, he also wonders if an apology would be helpful. His solution is to contact survivors and ask them if they want an apology. After all, he says, survivors should not be used as victims again, to return to grace organizations whose fate may not interest them.

A mistake that both Markl and Winnacker - indeed, the whole community - could be making is to focus the debate so strongly on apology. Apology misguidedly associates the postwar generation directly with the activities of its predecessor. An expression of a sense of shame would be less of a hollow gesture, as it is a meaningful act to acknowledge and explicitly react to a horrific aspect of one's scientific heritage. The real issue, however, is that of their public recognition and condemnation of actions by scientists against Jews and other outcast groups and populations. Apologies may be due, rather, for the MPS's and DFG's ignoring of the issue until quite recently.

Were Markl and Winnacker publicly to issue to survivors statements of recognition and condemnation, they would demonstrate the total lack of acceptance by today's German scientific community of exploitation of humans in scientific experiments. It might also grant peace of mind to those in the scientific community haunted by the acts of a previous generation. 